\title{
CORPORATE GOVERNANCE OF STATE-OWNED ENTERPRISES: NATIONAL PRACTICES OF THE BOARD
}

\section{Spartak Keremidchiev ${ }^{2}$ Miroslav Nedelchev $^{3}$}

Received: 09.07.2020, Accepted: 11.08.2020

\begin{abstract}
The purpose of this article is to present good practices, experience and ideas related to the organization and functioning of the board of state-owned enterprises. Corporate governance practices are represented by three characteristics of the board: nomination, composition and remuneration.

The results of the article reveal a wide variety of board practices in different countries. They are determined by the state ownership policy of the respective country. Various practices and experiences are presented, which can be included in a kind of menu for selecting appropriate tools to promote and strengthen the boards, and thus the corporate governance of state-owned enterprises in Bulgaria.
\end{abstract}

Keywords: nomination, composition, remuneration

JEL Codes: D23, D86, G34, M12, P51

\section{Introduction}

In theory, the board of state-owned enterprises is viewed through the prism of the debate on the need for state ownership and the efficiency of state-owned enterprises. Researches on good practices on board builds on perceptions of the need for state-owned enterprises (Kim \& Chung, 2008). In parallel, there are strong arguments for the innate inefficiency of state-owned enterprises compared to the private sector (Alchian, 1965). The foundations of state-owned enterprises and their role in the efficient allocation of public resources have been criticized, which cannot be achieved given the lack of a motive for profit and incentives for managers whose income is not related to the performance of the enterprise (Domberger \& Piggott, 1994). Other arguments are directed at the state as a

\footnotetext{
${ }^{2}$ Economic Research Institute, Bulgarian Academy of Sciences, Prof., PhD, spartak@club2000.org, ORCID ID: https://orcid.org/0000-0003-1482-7546

${ }^{3}$ Economic Research Institute, Bulgarian Academy of Sciences, Chief Assist., PhD, mknedelchev@abv.bg, ORCID ID: https://orcid.org/0000-0003-2372-1049
} 
principal and the impossibility for it to withdraw from ownership if the goals of the enterprise are not achieved (Florio, 2004). Exercising control over stateowned enterprises solely through the budgetary framework is also considered a weakness in their governance (Chang, 2007). There is an understanding of the lack of corporate control and the impossibility of acquiring and buying a stateowned enterprise with low performance (Vickers \& Yarrow, 1988). These criticisms require answers both theoretical and practical aspect. Here are the answers that good practices provide.

\section{Practices of board of state-owned enterprises}

Modern reform in the field of state-owned enterprises is based on the triad related to the understanding of the nature of the state, the board and managers (OECD, 2013). The trend is to provide real decision-making powers and division of responsibilities for the decision taken. The ultimate goal of the reform is to avoid conflicts of interest and demotivating factors.

In the 1990s, the state acted as a passive shareholder and rarely used the board as a mechanism to exercise control over the management of the company (Grosman et al., 2016). At the beginning of the 21 st century, the state is more active in exercising its functions as a shareholder by nominating its senior officials to the boards of state-owned enterprises.

The widespread "commercialization" of state-owned enterprises in recent decades has prompted governments to take action to professionalize boards and give them greater powers and autonomy (OECD, 2013). This includes protecting boards from political interference and ensuring independence in decisionmaking. Another important step is to pay more attention to the composition of the board to ensure the right combination of skills and experience to achieve the goals of the state-owned enterprise.

\section{Nomination of board members}

An empirical study of the boards of state-owned enterprises defines the composition as a characteristic feature of the board together with its role and dynamics (Chambers \& Cornforth, 2010). Research on the composition of the board of state-owned enterprises is rare in the specialized literature.

In most countries, there are no standard procedures and criteria for nominating board members of state-owned enterprises, unlike in the private sector. In most cases, line ministries nominate board members through shareholders' meetings. This is the challenge of corporate governance of stateowned enterprises - to find a balance between the responsibilities of the state to 
actively perform its functions as owner in the nomination of board members, and at the same time to refrain from political interference in the enterprise (Erić \& Stošić, 2011). Improper state policy in the nomination of the board leads to public distrust due to the transformation of state-owned enterprises into an "extension of the ministry" (OECD, 2015c).

The quantitative composition of the board is easier to analyze and compare. Increased board composition does not necessarily mean better corporate governance (Chen, 2016). The first version of the 2005 OECD Guidelines for Corporate Governance of State-Owned Enterprises states that "determining the correct board size is an important issue in promoting the efficiency of boards", although there is no universal approach. The OECD's conclusions are aimed at increasing the number of board members in state-owned enterprises, although there has been a downward trend in recent years. At a later stage, the OECD noted that the optimal board size was between five and eight members (OECD, 2013).

The large number of board members leads to "clumsiness" (Robinett, 2006). The tendency to expand the composition leads to the board being considered as a kind of "parliament" in which a number of groups are represented, and not as a governing body of the enterprise. In certain cases, unique situations arise in which the number of board members is greater than the number of employees in the company (European Commission, 2016).

In determining the composition of the boards, the commitment of each of the nominees should be taken into account and the possibility for each member to pay due attention to the state-owned enterprise should be provided for. While in the private sector there is a restriction for one person not to hold positions on more than four boards, in the public sector there are paradoxical cases - only eight people hold positions on the boards of each of the 42 state forest enterprises in Lithuania (OECD, 2015c ). The situation is similar in the Lithuanian road maintenance sector, where five identical civil servants collectively manage the 11 state-owned enterprises in the sector.

An analysis of the boards of state-owned financial companies found a difference in the number of members - from two to fifteen for a period of one to six years (Ferrari et al., 2017). In about a third of the cases, the nomination is made by the shareholders, in a quarter by the legislature or the Minister of Finance, and to a lesser extent by the Prime Minister and other institutions (Chart $1)$. 
Chart 1. Leading authority in nomination of board members

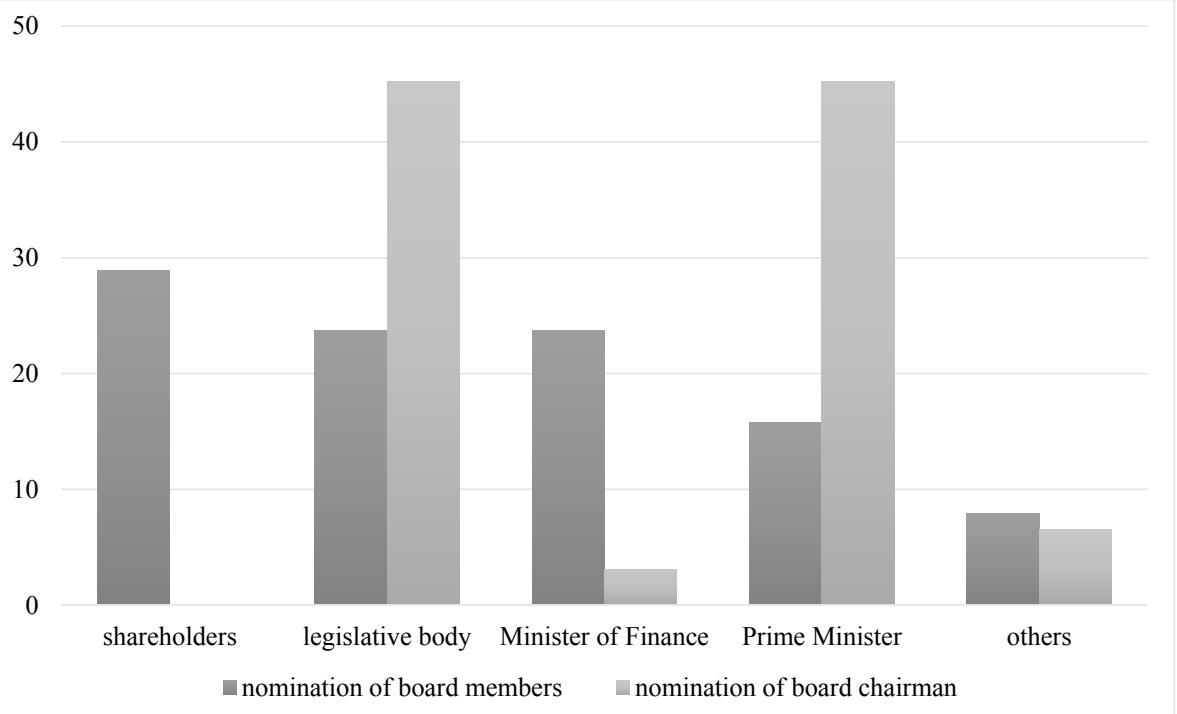

Source: Ferrari et al., 2017

The quality composition of the board reflects its professionalism. Minimum requirements are set for education and experience, and skills in finance, business, law and corporate governance have more weight in the nomination process. It is common practice for board members to be civil servants with no experience in running companies and to be nominated for political reasons rather than on the basis of their technical and financial expertise (World Bank, 2014b). In most countries, a combination of education and experience is used in board nomination (Table 1). It is recommended that private sector practices be applied in state-owned enterprises, such as the use of external consultants to recruit candidates and create databases for directors (OECD, 2013). 
Table 1. Regulatory framework for board nomination for OECD member countries

\begin{tabular}{|c|c|c|c|c|}
\hline & $\begin{array}{l}\text { Responsibility for } \\
\text { nomination }\end{array}$ & Qualification required & $\begin{array}{c}\text { Guidelines / restrictions } \\
\text { on members' } \\
\text { characteristics }\end{array}$ & $\begin{array}{l}\text { Public, private and } \\
\text { independent }\end{array}$ \\
\hline Austria & $\begin{array}{l}\text { The right to nominate is } \\
\text { exercised by the ultimate } \\
\text { owner, ie. the ministry that } \\
\text { administers the state-owned } \\
\text { enterprise }\end{array}$ & $\begin{array}{l}\text { Supervisory board } \\
\text { members must have "the } \\
\text { necessary qualifications and } \\
\text { experience" }\end{array}$ & $\begin{array}{l}\text { There is a quota for } \\
\text { women's representation }\end{array}$ & $\begin{array}{l}\text { Both public and } \\
\text { independent }\end{array}$ \\
\hline Belgium & $\begin{array}{l}\text { Nomination by decree of } \\
\text { the King after consultation } \\
\text { with the Cabinet of } \\
\text { Ministers }\end{array}$ & $\begin{array}{l}\text { There are no formal } \\
\text { requirements }\end{array}$ & $\begin{array}{l}\text { Board members have limits } \\
\text { on the number of } \\
\text { directorships they can hold }\end{array}$ & $\begin{array}{l}\text { Both public and } \\
\text { independent }\end{array}$ \\
\hline Brazil & $\begin{array}{l}\text { One member is nominated } \\
\text { by the Ministry of } \\
\text { Planning, Budget and } \\
\text { Management. The other } \\
\text { members are nominated by } \\
\text { the line ministry }\end{array}$ & $\begin{array}{l}\text { University degree required. } \\
\text { Other requirements are set } \\
\text { out in the company's } \\
\text { articles of association }\end{array}$ & $\begin{array}{l}\text { There are usually } \\
\text { restrictions only for } \\
\text { Brazilian citizens }\end{array}$ & $\begin{array}{l}\text { Mostly from the public } \\
\text { sector }\end{array}$ \\
\hline Canada & $\begin{array}{l}\text { Nomination by the relevant } \\
\text { minister }\end{array}$ & $\begin{array}{l}\text { There are no formal } \\
\text { requirements }\end{array}$ & $\begin{array}{l}\text { There are no formal } \\
\text { requirements }\end{array}$ & Mostly independent \\
\hline Chile & \begin{tabular}{|l|} 
Nomination by a \\
centralized ownership \\
system
\end{tabular} & $\begin{array}{l}\text { There are no formal } \\
\text { requirements }\end{array}$ & $\begin{array}{l}\text { The maximum number of } \\
\text { nomination per director is } \\
\text { five }\end{array}$ & Independent \\
\hline
\end{tabular}

Source: OECD, 2013.

In rare cases, such as in Argentina, there are no requirements for board skills and experience (OECD, 2018). In Lithuania, there is an inter-ministerial commission for the nomination of the board of large state-owned enterprises, which is guided by criteria such as financial expertise, experience in strategic planning and sector-specific knowledge and experience (OECD, 2015c). Boards in Colombia include ministers, and in some cases, executive directors are nominated directly by the president of the republic (OECD, 2015b).

States shall take steps to limit the nomination of government representatives on the boards of state-owned enterprises and, when nominated, to ensure that they meet the necessary qualifications and have the same duties and roles as any other member of the board. The steps in this direction are (World Bank, 2014b):

- Limiting the number of government representatives on the boards, while increasing the share of private sector members. For example, in Indian stateowned enterprises, a maximum of two government representatives can be nominated on the board, usually government officials from the relevant ministry.

- Prohibition of civil servants who have a regulatory function from nomination in boards. The practice in Malaysia in recent years has been related to the removal from the boards of government officials with a regulatory function 
for independent policy and increasing the business orientation of state-owned enterprises.

- In limited cases, in the nomination process, the government and each board agree annually for detailed financial objectives, based on the results of internationally competitors (World Bank, 2014a). In New Zealand, the expected dividends and other financial ratios are negotiated on a three-year basis as a result of the activities of state-owned enterprises.

\section{Independent directors and board committees}

The main mechanism for preventing conflicts of interest is the nomination of independent directors on the boards of state-owned enterprises (OECD, 2015c). In the practice of individual countries, their independence is often questioned (World Bank, 2014a). Current views on the number of independent directors are related to the ability and capacity of the board to make independent decisions (Chen, 2016).

Independent board members are primarily in charge of overseeing the state-owned enterprise and, to a lesser extent, a source of expertise (Robinett, 2006). Given the nature of independent directors, it is understandable that their market is limited in emerging market economies for both private and state-owned enterprises. In Colombia, the laws on state-owned enterprises, which are listed on the stock exchange, provide for a quota of at least $25 \%$ for independent directors. Lithuanian state-owned enterprises do not offer liability insurance to board members, which is an obstacle to attracting independent board members (OECD, 2015c).

The presence of board committees can reduce the negative influence of the state on the corporate governance practices of state-owned enterprises (Krause, 2013). Country practices converge on the existence of audit committees:

- In Argentina, there are legal requirements for the establishment of audit committees for registered companies, banks, stock exchanges and some stateowned enterprises (OECD, 2018). The Code of the National Securities Commission recommends the establishment of committees on remuneration, nominations, corporate governance and finance for listed companies. In practice, audit committees have the function of overseeing internal and external audits and risk management policies. The members of the audit committees must be trained to ensure the management of the company. The Banco de Inversión y Comercio Exterior SA has the largest number of committees: 1) audit committee, 2) credit and operations committee, 3) management committee, 4) money laundering 
prevention committee, 5) management committee risk, 6) Committee on Trust Funds and Infrastructure Projects, 7) Debt Recovery Committee.

- In Colombia, the establishment of an audit committee is mandatory for all state-owned enterprises (OECD, 2015b).

- In Latvia, the establishment of specialized committees on the board is voluntary and they serve as a useful means of communication between shareholders and the board (OECD, 2015a). Audit committees are most widespread. The telecommunications company Lattelecom has the most committees - a remuneration committee, a business planning and financing committee and an audit committee. The rules of procedure of these committees shall be mutually agreed by the members of the committees.

- In Lithuania, state-owned enterprises listed on stock exchange are required to establish audit committees (OECD, 2015c). For large state-owned enterprises, the establishment of an internal control committee and a remuneration committee is required.

- The situation is similar in Slovenia, where audit committees are mandatory for boards of state-owned enterprises (OECD, 2011).

\section{Remuneration of managers and executive directors}

Despite the differences in nature between the boards of public and private sector enterprises, there is a common feature related to agency conflict (Menozzi \& Urtiaga, 2008). One of the tools for reducing agency conflict is the remuneration mechanism. There are various practices for determining remuneration in different countries:

- Since 2010, in the Czech Republic was adopted principles for the remuneration of managers of state-owned enterprises. The principles apply good remuneration practices through standard structures and increase transparency. On an annual basis, principals inform the government of remuneration practices.

- In Finland, guidelines on management fees and pension benefits were adopted in 2009. Remuneration schemes are the responsibility of the chairman of the board and possibly the remuneration committee. Only independent board members are involved in remuneration decisions.

- In Norway, guidelines for the remuneration of management in stateowned enterprises have been in force since 2006. They require state-owned enterprises not to use stock options in their management remuneration programs.

- Since 2015, Poland's remuneration policy for state-owned enterprises has been aimed at converging with that in the private sector. 
- Since 2009, in Sweden, the remuneration of the CEO has been the responsibility of the board. The Board should ensure that the remuneration of both the Chief Executive Officer and other executives remains within the guidelines set by the annual general meeting of shareholders.

From the analysis of the literature the following specifics of the remuneration of the members of the board in the state enterprises can be determined:

- Board members nominated by ministers and employees' representatives, as well as non-executive members, shall not receive compensation other than a nominal fee (Robinett, 2006).

- For state-owned enterprises, the lack of external control, such as access to capital markets, makes it difficult to assess the effectiveness of managers (Sokol, 2009).

- Managers of state-owned enterprises have lower incentives to perform than private enterprises, as state-owned enterprises are usually subject to "soft" budgetary constraints and are protected from bankruptcy and hostile takeovers. (Pargendler, 2012).

- The practice in Serbia, aimed at fixed remuneration of executive directors of state-owned enterprises, does not link the results achieved with bonuses and sanctions. Successful and unsuccessful CEOs receive equal recognition, and attracting good CEOs is very difficult. (Mirić et al., 2018).

In most countries, the remuneration of board members of state-owned enterprises is below market levels for the necessary competencies and experience (OECD, 2013). As a general rule, governments tend to limit the remuneration and incentives of both CEOs and board members. Some countries seek to equate pay with market conditions, but not to be market leaders, while others are significantly more restrictive.

The models used are: 1) limiting the remuneration to the fee for attending a board meeting; 2) limitation of the remuneration of the directors in relation to the average salary for the state enterprises; and 3) developing a "fee policy", taking into account factors such as the size of state-owned enterprises, time requirements and formal qualifications.

\section{Conclusion}

Modern practices on board are shaped by national state ownership policy. The key trends in the development of the boards can be expressed as professionalization, depoliticization and achievement of pre-set financial goals. With regard to the size of the board, no direct relationship has been established between the number of its members and the performance of state-owned 
enterprises. In most cases, the number of board members is between five and eight. To ensure professionalization of the board, requirements for qualification and experience in management, finance and corporate governance are applied. The participation of civil servants in the boards is limited and rules are developed to determine the remuneration of its members.

The main tools in the individual practices are the specialized committees, which in most cases are the audit committee and the risk assessment committee, as well as the nomination of independent directors on the boards of state-owned enterprises to prevent conflicts of interest. Independent board members perform primarily supervisory functions in the state-owned enterprise and are less of a source of expertise.

The study of foreign practices and experience in corporate governance of state-owned enterprises reveals a wide range of policies and tools that are applied in different countries. Most of them are based on the OECD guidelines for corporate governance of state-owned enterprises. The conclusion that can be made regarding the Bulgarian situation is that good examples and practices exist, they are constantly evolving and enriching. Their use is the result of combining centralized efforts with ingenuity and creativity at the level of a state-owned enterprise.

\section{REFERENCES}

Alchian, A. (1965). Some Economics of Property Rights. Il Politico, 30, 816829.

Chambers, N. \& Cornforth, C. (2010). The role of corporate governance and boards in organisational performance. In Walshe, K., Harvey, G. \& Jas, P. (eds.) Connecting Knowledge and Performance in Public Services: From Knowing to Doing. Cambridge: Cambridge University Press.

Chang, H. (2007). State-Owned Enterprise Reform. New York: United Nations.

Chen, C. (2016). Solving the puzzle of corporate governance of state-owned enterprises: The path of Temasek model in Singapore and lessons for China. Northwestern Journal of International Law and Business, 36(2), 303-370.

Domberger, S. \& Piggott, J. (1994). Privatization Policies and Public Enterprise: a Survey. In Bishop, M., Kay, J. \& Mayer, C. Privatisation and Economic Performance. Oxford: Oxford University Press.

Erić, D. \& Stošić, I. (2011). Upgrading corporate governance practice of state owned enterprises in processes of EU integration - comparation of Serbia and Slovenia. In Contemporary issues in the integration processes of Western Balkan countries in the European Union. International Center for Promotion of Enterprise, Ljubljana, 234-236. 
European Commission. (2016). State-Owned Enterprises in the EU: Lessons Learnt and Ways Forward in a Post-Crisis Context. Institutional paper 031. Brussels.

Ferrari, A., Mare, D. \& Skamnelos, I. (2017). State Ownership of Financial Institutions in Europe and Central Asia. Policy Research Working Paper 8288. Washington, DC: World Bank.

Florio, M. (2004). The Great Divestiture: Evaluating the Welfare Impact of the British Privatizations 1979-1997. MIT Press.

Grosman, A., Okhmatovskiy, I. \& Wright, M. (2016). State Control and Corporate Governance in Transition Economies: 25 Years on from 1989. Corporate Governance: An International Review, 24(3), 200-221.

Kim, J. \& Chung, H. (2008). Empirical Study on the Performance of Stateowned-enterprises and the Privatizing Pressure: The Case of Korea. Seoul National University.

Krause, T. (2013). Corporate Governance of Corporate Government: A Literature Review on the Relationship between Internal Corporate Governance Practices and Performance in State Owned Enterprises. Tabled Paper prepared for the Annual Conference of the European Group for Public Administration (EGPA), 2013, Edinburgh, Scotland in the Study Group V "Regional and Local Government".

Menozzi, A. \& Urtiaga, M. (2008). Board composition and performance in StateOwned Enterprises: evidence from the Italian public utilities sector. European Financial Management Association 2008 Annual Meeting.

Mirić, A., Todorović, M. \& Janićijević, N. (2018). How can the efficiency of corporate governance in Serbian state-owned enterprises be increased? Ekonomski anali, 63(216), 63-84.

OECD. (2011). State-Owned Enterprise Governance Reform. An Inventory of Recent Change. Paris: OECD Publishing.

OECD. (2013). Boards of Directors of State-Owned Enterprises: An Overview of National Practices. Paris: OECD Publishing.

OECD. (2015a). OECD Review of the Corporate Governance of State-Owned Enterprises. Latvia. Paris: OECD Publishing.

OECD. (2015b). OECD Review of the Corporate Governance of State-Owned Enterprises. Colombia. Paris: OECD Publishing.

OECD. (2015c). OECD Review of the Corporate Governance of State-Owned Enterprises. Lithuania. Paris: OECD Publishing. 
OECD. (2018). OECD Review of the Corporate Governance of State-Owned Enterprises. Argentina. Paris: OECD Publishing.

Pargendler, M. (2012). State Ownership and Corporate Governance. Fordham Law Review, 80(6), 2917-2973.

Robinett, D. (2006). Held by the Visible Hand. The Challenge of SOE Corporate Governance for Emerging Markets. Washington, DC.: World Bank.

Sokol, D. (2009). Competition Policy and Comparative Corporate Governance of State-Owned Enterprises. Brigham Young University Law Review, Vol. 2009, No. 1713-1812. Gainesville: University of Florida Levin College of Law.

Vickers, J. \& Yarrow, G. (1988). Privatization: an economic analysis. MIT Press.

World Bank. (2014a). Corporate Governance of State-Owned Enterprises in Latin America: Current Trends and Country Cases. Report No.: 89468-LAC. Washington, DC.

World Bank. (2014b). Corporate governance of state-owned enterprises: A Toolkit. Washington, DC. 